\title{
Autologous Anti-NY-ESO-1 mTCR Retroviral Vector Transduced PBLs
}

National Cancer Institute

\section{Source}

National Cancer Institute. Autologous Anti-NY-ESO-1 mTCR Retroviral Vector

Transduced PBLS. NCI Thesaurus. Code C157409.

Human autolog ous peripheral blood lymphocytes (PBLS) transduced with a retroviral vector encoding both alpha and beta chains of a murine T-cell receptor (mTCR) specific for the cancer-testis antigen NY-ESO-1, with potential antineoplastic activity. Upon isolation, transduction, expansion ex vivo, and reintroduction into the patient, the autolog ous anti-NY-ESO-1 mTCR retroviral vector transduced PBLs bind to NY-ESO-1 expressed on tumor cells. This may result in cytotoxic T-lymphocyte (CT L)-mediated killing of NY-ESO-1-positive cancer cells. NY-ESO-1, a tumor-associated antigen (TAA), is found in normal testis and on the surface of various tumor cell types. 